\title{
EVALUASI KURIKULUM AL-ISLAM KEMUHAMMADIYAHAN DI FAKULTAS EKONOMI DAN BISNIS UNIVERSITAS MUHAMMADIYAH PALEMBANG
}

\author{
Anica, Romli, dan Nyayu Khodijah \\ ${ }^{1}$ Universitas Islam Negeri Raden Fatah, Palembang, Indonesia \\ anica10ica@gmail.com \\ ${ }^{2}$ Universitas Islam Negeri Raden Fatah, Palembang, Indonesia \\ romlisa_uin@radenfatah.ac.id \\ ${ }^{3}$ Universitas Islam Negeri Raden Fatah, Palembang, Indonesia \\ nyayu_dd@yahoo.com
}

\begin{abstract}
Changes in the curriculum of al-Islam Kemuhammadiyahan 1 course at the Muhammadiyah University of Palembang became a challenge for lecturers in preparing semester learning plans and implementation of learning to adjust to the National Standards of Higher Education, because in addition to being a national compulsory subject known as Islamic Religious Education with the number 2 credits are also compulsory courses at the University of Muhammadiyah Palembang. This study uses the Countenance evaluation model popularized by Stake, namely two main matrices in the description of descriptions and judgments As for the results of this research found, the documents contained in the al-Islam semester learning plan Kemuhammadiyahan 1 (Islamic Religious Education) have met the criteria of the National Standards of Higher Education but in the learning methods section and assessment indicators do not meet the criteria of the National Standards of Higher Education. While the learning process of the al-Islam Muhammadiyah Center 1 Faculty of Economics and Business shows a discrepancy with the semester learning plan of the Kemuhammadiyahan al-Islamic course due to ineffective use of time in the learning process. And students can understand and try to practice well the basics of the Islamic religion.
\end{abstract}

Keywords: Evaluation, Curriculum, al-Islam Kemuhammadiyahan.

\section{INFORMASI ARTIKEL}

Submitted, February 09, 2019

Revised, April 13, 2019

Accepted, June 07, 2019 


\section{PENDAHULUAN}

Lembaga pendidikan di Indonesia merupakan aspek penting sebagai penunjang pembagunan nasional yang memiliki tanggung jawab dalam mewujudkan manusia atau masyarakat yang berkualitas (Dawam, 2004). Diakui bahwa Indonesia bukan negara agama, meskipun demikian nilai-nilai agama sangat dominan menjiwai rakyatnya dalam kehidupan pribadi, bekeluarga, bermasyarakat, berbangsa dan bernegara. Namun dalam realitas sosial, pada banyak lembaga pendidikan tinggi baik negeri maupun swasta mengalami berbagai permasalahan yang dihadapi dalam penyelenggaraan pendidikan tinggi. Dalam hal ini perlunya melakukan sebuah evaluasi dalam bidang pendidikan dan pengajaran.

Evaluasi merupakan bagian dari sistem manajemen yaitu perencanaan, organisasi, pelaksanaan, monitoring dan evaluasi. Kurikulum juga dirancang dari tahap perencanaan, organisasi kemudian pelaksanaan dan akhirnya monitoring dan evaluasi. Tanpa evaluasi, maka tidak akan mengetahui bagaimana kondisi kurikulum tersebut dalam rancangan, pelaksanaan serta hasilnya. Setiap program, kegiatan-kegiatan atau sesuatu yang direncanakan selalu diakhiri dengan evaluasi. Evaluasi dimaksudkan untuk melihat kembali apakah suatu program atau kegiatan telah sesuai dengan perencanaan atau belum.

Dari kegiatan evaluasi akan diketahui hal-hal yang telah dan akan dicapai, sudahkah memenuhi kriteria yang ditentukan. Berdasarkan hasil evaluasi tersebut kemudian diambil keputusan apakah program tersebut akan diteruskan ataukah direvisi atau bahkan diganti seluruhnya. Kegiatan pengembangan kurikulum juga tidak akan lepas dari unsur evaluasi, karena evaluasi merupakan salah satu komponen yang amat penting yang tidak dapat diabaikan begitu saja. Dalam banyak hal, komponen penilaian sangat berperan dalam menunjang keberhasilan pengembangan kurikulum, seperti yang kita ketahui, kurikulum yang dikembangkan itu masih berupa perencanaan-perencanaan bersifat teoritis dan abstrak. Dengan adanya evaluasi, kita akan memperoleh gambaran mengenai keberhasilan kurikulum yang sedang dan telah dikembangkan di sekolah-sekolah.

Dari kegiatan evaluasilah akan diketahui kelebihan, kelemahan dan kekurangankekurangannya. Dalam kerangka ini, maka harus juga melihat bahwa keberhasilan sebuah lembaga pendidikan adalah terletak pada sejauh mana evaluasi itu dilaksanakan begitu juga dalam pendidikan Islam. evaluasi kurikulum ini sangat penting untuk mengetahui sejauh mana pelaksanaan dan pengajaran di lembaga-lembaga pendidikan Islam itu dijalankan. lembaga-lembaga pendidikan Islam itu dijalankan. Pada tahun tahun 2016, pemerintah melalui Kementerian Riset, Teknologi dan Pendidikan Tinggi kembali mencanangkan penerapan Kerangka Kualifikasi Nasional Indonesia (KKNI) di perguruan tinggi yang mengacu pada Pasal 15 Permenristekdikti No. 100 Tahun 2016, untuk menguatkan akuntabilitas penyelenggaraan pendidikan sekaligus menjamin kualitas lulusan pada lembaga pendidikan tinggi. Salah satu organisasi sosial Islam yang memiliki lembaga pendidikan tinggi yang terpenting di Indonesia sebelum Perang Dunia II dan mungkin juga sampai saat ini, tegas Deliar Noer (Noer, 1999), adalah Muhammadiyah.

Bagi warga Muhammadiyah pendidikan memiliki kedudukan yang sangat strategis dalam pencapaian maksud dan tujuan Muhammadiyah yakni menegakkan dan menjunjung tinggi agama Islam sehingga terwujud masyarakat Islam yang sebenar-benarnya (Keputusan Muktamar Muhammadiyah ke 45 Tahun 2005). Menurut Muhammadiyah tujuan itu dapat dicapai dengan melaksanakan dakwah yang salah satuny melalui pendidikan. Dengan demikian, visi dan misi pendidikan Muhammadiyah tentunya selalu konsisten dan berorientasi pada maksud dan tujuan pendidikan Muhammadiyah itu sendiri. Dalam konteks ini menarik memperhatikan pernyataan mantan Ketua Pimpinan Wilayah Muhammadiyah Jawa Barat Hidayat Salim yang mengatakan bahwa Muhammadiyah adalah gerakan tajdid atau pembaharuan yang ditujukan pada dua bidang. Yaitu bidang pengajaran/pedidikan dan 
bidang pemikiran. Pembaharuan dalam pengajaran/pendidikan dititik beratkan pada purifikasi ajaran Islam dengan berpedoman kembali pada al-Qur'an dan as-Sunnah dengan menggunakan akal pikiran yang sehat. Pembaharuan dalam bidang pemikiran adalah pengembangan wawasan pemikiran (visi) dalam melaksanakan ajaran berkaitan mu'amalah duniawiyah yang diizinkan syara' atau modernisasi pengelolaan dunia sesuai dengan ajaran Islam, seperti pengelolaan negara dan aspek-aspek yang berkaitan dengan kehidupan bidang ekonomi, politik, sosial, budaya dan pertahanan keamanaan sehingga terwujud masyarakat utama, adil, dan makmur yang diridhai Allah SWT. Sedangkan misi utama gerakan Muhammadiyah adalah menegakkan dan menjunjung tinggi agama Islam dalam pengertian melaksanakan ajaran Islam melalui dakwah Islam amar ma'ruf nahi munkar di berbagai kegiatan (Keputusan Muktamar Muhammadiyah ke 45 Tahun 2005). Mengikuti pemikiran Hidayat Salim di atas dapat ditegaskan bahwa visi yang diemban oleh pendidikan muhammadiyah adalah pengembangan wawasan intelektual peserta didik pada setiap jenis dan jenjang pendidikan yang dikelola oleh organisasi Muhammadiyah, sedangkan misi yang diemban pendidikan Muhammadiyah adalah menegakkan dan menjunjung tinggi agama Islam melalui dakwah Islam amar ma'ruf nahi munkar di semua aspek kehidupan. Implementasi visi dan misi pendidikan Muhammadiyah ini tentunya mendapat penekanan atau prioritas yang berbeda-beda sesuai dengan jenis dan jenjang pendidikannya. Seperti visi dan misi yang ada dalam Perguruan Tinggi Muhammadiyah Palembang sebagai berikut: Pertama, "Menjadi universitas berstandar nasional dan menghasilkan lulusan berdaya saing tinggi serta unggul dalam iptek yang berbasis keislaman pada tahun 2022 menuju universitas berstandar internasional”.

Dengan adanya peraturan tersebut, lembaga pendidikan tinggi dalam hal ini salah satunya Universitas Muhammadiyah Palembang perlu menyesuaikan dengan peraturan yang akan diterapkan oleh Kementerian Riset, Teknologi dan Pendidikan Tinggi dalam rangka penyetaraan perguruan tinggi swasta. Sebagaimana Perguruan Tinggi di Indonesia yang menurut Nizam (2006) perguruan tinggi di Indonesia dihadapkan tantangan penting yaitu (a) peningkatan kualitas, relevansi, ekuiti, efesiensi, dan governance, (b) posisi perguruan tinggi sebagai kekuatan moral yang diperuntukkan untuk mengarahkan demokrasi di masyarakat dan reformasi sosial politik, dan (c) munculnya akibat kontruksi ekonomi, pengetahuan, internasionalisasi dan kompetensi antar negara yang semakin meningkat. Hal inilah yang harus disikapi oleh pendidikan tinggi termasuk Perguruan Tinggi Muhammadiyah Palembang mengingat kurikulum mata kuliah al-Islam kemuhammadiyahan sudah diterapkan beberapa tahun terakhir dalam belum pernah dilakukan evaluasi lebih lanjut. Sebagai perguruan tinggi swasta Universitas Muhammadiyah Palembang merupakan lembaga pengembangan sumber daya manusia yang manusia yang unggul dan islami sebagai pemasok ke dalam pasar kerja yaitu para lulusan menjadi outcome dan memiliki learning outcome untuk mencapai tujuan ideal Perguruan Tinggi Muhammadiyah, dan sangat wajar apabila Perguruan Tinggi Muhammadiyah terus berupaya meningkatkan mutu pendidikan.

Untuk mencapai tujuan di atas dibutuhkan adanya pengembangan dan evaluasi kurikulum sebagai salah satu hal mendasar dalam Perguruan Tinggi. Kurikulum secara esensi merupakan sebuah program untuk mencapai tujuan pendidikan (Tafsir, 2010), seperti halnya yang dikatakan Nasution bahwa lazimnya kurikulum sebuah rencana yang disusun untuk memudahkan proses kegiatan belajar mengajar yang dibimbing dan ditanggungjawabkan oleh sekolah atau sebuah lembaga pendidikan dan staf pengajaran. Kurikulum menjadi aspek penting dalam rangka mencapai tujuan pendidikan yang ditetapkan oleh setiap institusi pendidikan sebagai aspek penting inilah maka kurikulum harus bersifat anticipatory dan adaptif terhadap kemajuan ilmu pengetahuan dan teknologi. Kurikulum juga harus responsip terhadap setiap perubahan yang terjadi dan dilakukan perkembangan yang didasarkan pada 
beberapa prinsip, yakni berorientasi pada tujuan, relevansi kurikulum dengan kebutuhan, efesiensi dan efektivitas dalam pelaksanaan, fleksibelitas, kesinambungan, xketerpaduan serta prinsip mutu.

Perubahan ini menjadi bahan evaluasi bagi Universitas Muhammadiyah Palembang untuk menyesuaikan penerapan kurikulum sesuai Standar Nasional Pendidikan Tinggi (SNPT). Mengingat evaluasi yang efektif dan efisien dilakukan secara kontinu serta menyeluruh diharapkan dosen dapat memperoleh gambaran secara utuh tentang prestasi dan kemajuan proses serta hasil yang dicapai pada mata kuliah al-Islam Kemuhammadiyahan dalam hasil temuan yang dilakukan peneliti dengan melakukan kegiatan interview dengan Wakil Dekan IV Fakultas Ekonomi dan Bisnis dan dua orang dosen al-Islam Kemuhammadiyahan Fakultas Ekonomi dan Bisnis pada tanggal 7 September 2018, menunjukkan bahwa kurikulum al-Islam Kemuhammadiyahan perlu di lakukan evaluasi baik secara dokumen perencanaan pembelajaran, konten/isi, dan pada hasil pelaksanaan. Sehingga sangat perlu mata kuliah al-Islam Kemuhammadiyahan dilakukan sebuah evaluasi lebih lanjut sebagai bahan perbaikan dan masukan untuk Fakultas Ekonomi dan Bisnis Universitas Muhammadiyah Palembang.

\section{METODOLOGI PENELITIAN}

Metode yang digunakan dalam penelitian ini yaitu kualitatif deskriptif. Dengan pendekatan penelitian evaluasi menggunakan model Countenance Stake. Pendekatan ini sangat cocok sebagai metode dalam penelitian ini, karena penelitian ini mengungkap sejauhmana pelaksanaan kurikulum khususnya pada aspek penyusunan pembelajaran semester mata kuliah. Model Countenance dipilih karena pertama, tujuan dari model ini adalah membuat kerangka guna mengevaluasi perencanaan. Kedua, Model ini menekankan pada evaluasi pelaksanaan kurikulum. Ketiga, Model ini menganjurkan pada evaluator untuk menggunakan beragam standard dalam mengevaluasi kurikulum supaya pandangan akan kurikulum dapat dikaji secara luas. Keempat, model Stake menekankan evaluasi pelaksanaan pembelajaran secara menyeluruh, tidak hanya terbatas pada perubahan perilaku peserta didik tetapi juga pada seluruh komponen yang berpengaruh dalam implementasi pembelajaran (Hasan, 2012). Dalam Hamid Hasan dijelaskan bahwa model evaluasi ini menekankan pada dua matriks utama dalam penggambarannya yaitu deskripsi (desriptions) dan pertimbangan (judgments). Penggambaran dilakukan pada masing-masing tahap antecedent (pendahuluan yaitu kondisi awal yang mungkin berdampak pada hasil), transaction (proses), dan outcomes (hasil) (Hasan, 2012).

Data hasil deskripsi dibandingkan dengan standar untuk melihat kesesuaian lalu diberikan pertimbangan. Matriks pertimbangan baru dapat dikerjakan oleh evaluator setelah matriks deskripsi diselesaikan. Setiap matriks terdiri atas dua kategori dan tiga bagian. Matriks deskripsi terdiri atas dua kategori rencana (intent) dan observasi. Matriks pertimbangan terdiri atas kategori standar dan pertimbangan.

Pada setiap kategori terdapat tiga fokus penting yang didasarkan pada pikiran Stake bahwa suatu evaluasi formal harus memberikan perhatian terhadap keadaan sebelum suatu kegiatan kelas berlangsung, ketika kegiatan berlangsung, dan menghubungkannya dengan berbagai bentuk hasil belajar. Pikiran ini diterjemahkan dalam istilah antecedents, transaksi, dan outcomes. Antecedents adalah keadaan sebelum, transaksi adalah proses, dan hasil kemampuan yang diperoleh peserta didik.

Berikut gambar tentang data hasil evaluasi Stake Countenance Models pegolahan data dikategorisasikan dan dideskripsikan kemudian diolah dengan konsep keseluruhan sebagai berikut (Hasan, 2012): 
Description Matrix

Judgement Matrix

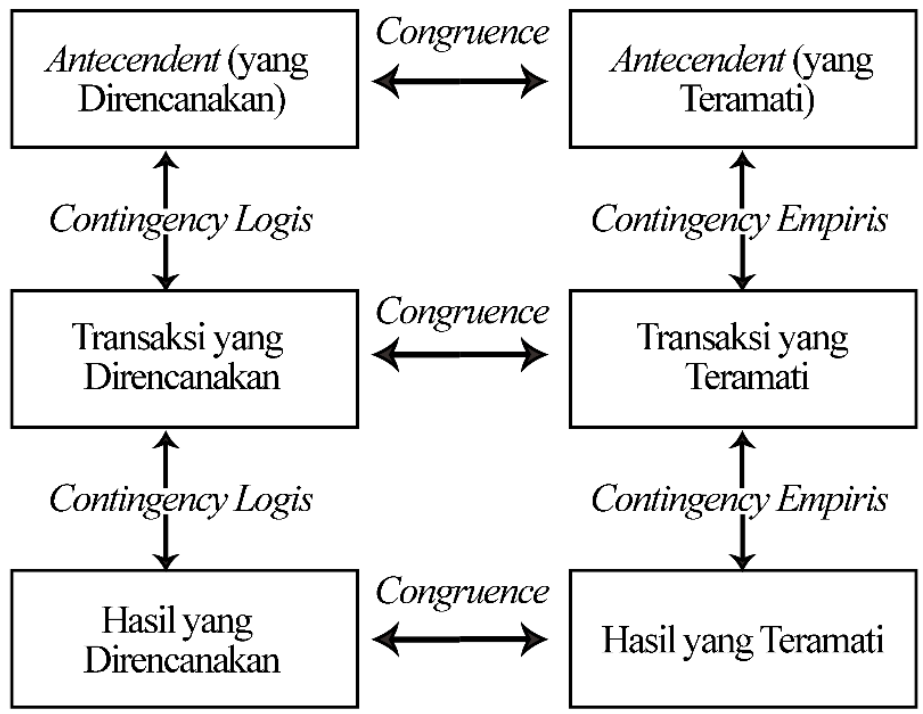

\section{Gambar 1. Skema Model Pengolahan Data Deskripsi dari Model Stake}

Pada penelitian ini Evaluasi kurikulum yang dilakukan mencakup tiga dimensi, yaitu dimensi dokumen, dimensi proses dan dimensi hasil. Pertama, dimensi dokumen yang diteliti meliputi tujuan mata kuliah al-Islam Kemuhammadiyahan 1, materi mata kuliah al-Islam Kemuhammadiyahan 1, strategi/metode pembelajaran mata kuliah al-Islam Kemuhammadiyahan 1 dan evaluasi/penilaian mata kuliah al-Islam Kemuhammadiyahan 1. Kedua, dimensi proses yang diteliti meliputi pelaksanaan pembelajaran mata al-Islam Kemuhammadiyahan 1 sesuai dengan rencana pembelajaran semester mata kuliah al-Islam Kemuhammadiyahan 1 antara yang disusun dengan yang dilaksanakan. Dan ketiga dimensi hasil yang diteliti meliputi pemahaman mahasiswa dalam pembelajaran mata kuliah al-Islam Kemuhammadiyahan 1 oleh mahasiswa.

\section{HASIL DAN PEMBAHASAN}

\section{Dokumen Perencanaan Pembelajaran Mata Kuliah Al-Islam Kemuhammadiyahan 1 Fakultas Ekonomi dan Bisnis}

Dari hasil wawancara ini disampaikan juga oleh Wakil Dekan I untuk terus berupaya melakukan perbaikan sebagai kualifikasi terhadap lulusan perguruan tinggi di Indonesia, pemerintah menerbitkan peraturan Presiden nomor 08 tahun 2012 tentang Kerangka Kualifikasi Nasional Indonesia (KKNI) dan lampirannya yang menjadi acuan dalam penyusunan capaian pembelajaran lulusan dari setiap jenjang pendidikan secara nasional, juknis Perpres ini Permendikbud nomor 73 tahun 2013. Terbitnya Perpres nomor 08 tahun 2012 dan Undang- Undang Perguruan Tinggi nomor 12 tahun 2012 pasal 29 ayat (1), (2) dan (3) telah berdampak pada kurikulum dan pengelolaannya disetiap program. Kurikulum yang pada awalnya mengacu pada pencapaian kompetensi menjadi mengacu pada capaian pemb elajaran (Learning outcomes). Capaian Pembelajaran (Learning outcomes) merupakan internalisasi dan akumulasi ilmu pengetahuan, keterampilan, sikap dan kompetensi yang dicapai melalui proses pendidikan yang terstruktur dan mencakup suatu bidang ilmu atau keahlian tertentu atau melalui pengalaman kerja (Hasil wawancara pada tanggal 20 Mei 2019). 
Sedangkan dari hasil wawancara dengan Wakil Dekan I menyebutkan bahwa mata kuliah al-Islam Kemuhammadiyahan memiliki kontribusi dalam kurikulum Fakultas Ekonomi dan Bisnis. Pada tahapan perencanaan pembelajaran dilakukan secara sistematis, logis dan terukur agar dapat menjamin tercapainya capaian pembelajaran lulusan. Selain itu untuk merumuskan capaian pembelajaran mata kuliah diturunkan menjadi beberapa sub capaian pembelajaran mata kuliah sesuai dengan tahapan belajar atau sering disebut lesson learning outcomes. Sub capaian mata kuliah bersifat dapat diamati, dapat diukur dan dinilai, lebih spesifik terhadap mata kuliah. Berikut perumusan capaian pembelajaran mata kuliah:

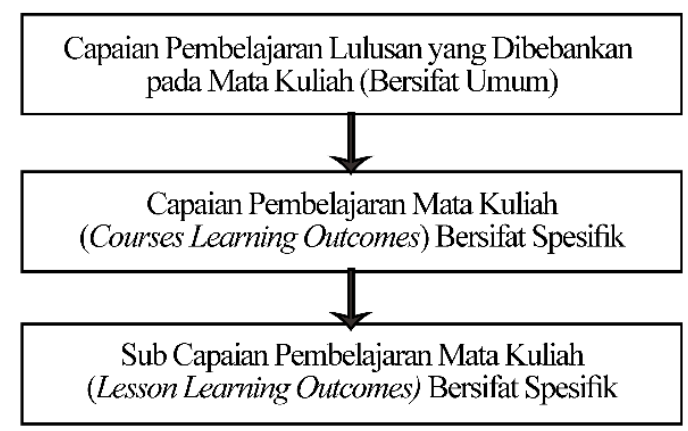

Gambar 2. Rumusan Capaian Pembelajaran

Seperti yang telah dijelaskan sebelumnya bahwa pembentukan mata kuliah didasarkan dengan capaian pembelajaran lulusan yang dibebankan pada mata kuliah dan bahan kajian yang sesuai dengan kebutuhan capaian lulusan tersebut. Berikut adalah hasil studi dokumen terhadap capaian pembelajaran mata kuliah al-Islam Kemuhammadiyahan 1 (Pendidikan Agama Islam) :

Tabel 1. Capaian Pembelajaran Prodi S1 Fakultas Ekonomi dan Bisnis yang dibebankan

\begin{tabular}{cl}
\hline Kode & \multicolumn{1}{c}{ Capaian Pembelajaran Prodi S1 Fakultas Ekonomi dan Bisnis yang dibebankan } \\
\hline S9 & $\begin{array}{l}\text { Menunjukkan sikap bertanggung jawab atas pekerjaan dibidang keahlian secara mandiri } \\
\text { Mengetahui nilai-nilai keislaman serta norma dalam mengemban profesi sebagai pendidik dan } \\
\text { tenaga kependidikan dan mengetahui peran dalam berbagai team-work } \\
\text { P10 }\end{array}$ \\
Kampu menerapkan pemikiran logis, kritis, sistematis, dan inovatif dalam konteks \\
pengembangan atau implementasi ilmu pengetahuan dan teknologi yang memperlihatkan dan \\
menerapkan nilai humaniora yang sesuai dengan bidang keahliannya \\
KU2 & $\begin{array}{l}\text { Mampu menunjukkan kinerja mandiri, bermutu dan terukur } \\
\text { Kampu memanfaatkan teknologi informasi dan komunikasi untuk pengembangan keilmuan } \\
\text { dan kemampuan kerja }\end{array}$ \\
M10 & $\begin{array}{l}\text { Memiliki moral, etika, tanggung jawab, kepribadian dan kemandirian yang islami dalam } \\
\text { pembelajaran dan menyelesaikan tugasnya. }\end{array}$ \\
\hline
\end{tabular}

Sedangkan untuk capaian pembelajaran mata kuliah (CPMK) al-Islam Kemuhammadiyahan 1 (Pendidikan Agama Islam) sebagai berikut:

Tabel 2. Capaian pembelajaran mata kuliah AIK 1 (Pendidikan Agama Islam)

\begin{tabular}{cl}
\hline Nomor & \multicolumn{1}{c}{ Capaian Pembelajaran mata kuliah AIK 1 (Pendidikan Agama Islam) } \\
\hline 1 & Mahasiswa mampu memahami dasar-dasar agama Islam dan sumber hukum dalam Islam \\
2 & Mahasiswa mampu memahami dan mengamalkan dasar-dasar aqidah Islam dan arkanul iman \\
3 & $\begin{array}{l}\text { Mahasiswa mampu memahami dan menginternalisasikan tauhid kepada Allah SWT dalam kehidupan } \\
\text { sehari-hari }\end{array}$ \\
4 & $\begin{array}{l}\text { Mahasiswa mampu memahami dan mengamalkan dasar-dasar ibadah, akhlak, dan muamalah dalam } \\
\text { Islam serta klasifikasi dan prinsip-prinsipnya. }\end{array}$ \\
\hline
\end{tabular}


Dari tabel di atas diuraikan beberapa kemampuan akhir bagi mahasiswa yang diharapkan dalam pembelajaran mata kuliah al-Islam Kemuhammadiyahn 1 (Pendidikan Agama Islam). Maka komponen penyusunan rencana pembelajaran dan perumusan capaian pembelajaran mata kuliah AIK 1 (Pendidikan Agama Islam) mengacu pada panduan penyusunan capaian pembelajaran kurikulum pendidikan tinggi (Panduan Penyusunan Kurikulum SNPT, 2016: 19).

Analisis pembelajaran dilakukan dengan dasar pemikiran bahwa dalam sebuah mata kuliah terjadi dengan tahapan-tahapan pencapaian kemampuan mahasiswa yang terukur, sistematis dan terencana. Analisis pembelajaran dilakukan untuk mengidentifikasi kemampuan akhir pada tiap tahapan sub capaian pembelajaran mata kuliah sebagai penjabaran capaian pembelajaran lulusan yang dibebankan pada mata kuliah tersebut.

Rencana pembelajaran semester ini juga diadakan workshop, hal ini tersirat dalam hasil wawancara Wakil Dekan IV Fakultas Ekonomi dan Bisnis menjelaskan muatan dokumen yang ada dalam rencana pembelajaran semester mata kuliah al-Islam Kemuhammadiyahan. Selaras dengan apa yang ada dipanduan rencana pembelajaran semester mata kuliah al-Islam Kemuhammadiyahan mengacu Kerangka Kualifikasi Nasional Indonesia dan Standar Pendidikan Tinggi. Untuk itu setiap dosen diharapkan dapat mengembangkan secara optimal rencana pembelajaran semester kepada tahap pelaksanaanya.

\section{Proses pembelajaran semester mata kuliah al-Islam Kemuhammadiyahan 1 Fakultas Ekonomi dan Bisnis}

Dalam proses pembelajaran pemilihan strategi pembelajaran harus dipertimbangkan pada kesesuaian dalam memberikan capaian pembelajaran lulusan, seperti sudah dijelaskan sebelumnya. Sebagai contoh, kemampuan untuk mempraktikkan shalat jenazah tidak mungkin bisa dicapai melalui ceramah dan ujian tertulis. Dengan demikian capaian pembelajaran harus menjadi dasar dalam pemilihan bentuk atau strategi pembelajarannya.

Pembelajaran yang berpusat pada mahasiswa menjadi prinsip utama, yakni dengan menggunakan pendekatan pembelajaran yang berprinsip pada Student Centered Learning (SCL). Dalam pendekatan pembelajaran yang akan dilaksanakan dalam proses pembelajaran yaitu Student Centered Learning (SCL), yang sesuai dengan prinsip pembelajaran mengacu pada Kerangka Kualifikasi Nasional Indonesia dan Standar Pendidikan Tinggi. Dalam proses pembelajaran yang akan dilaksanakan, bahwa peran dosen yaitu: a). bertindak sebagai fasilitator dan motivator dalam proses pembelajaran, b). mengkaji kompetensi mata kuliah yang perlu dikuasi oleh mahasiswa di akhir pembelajaran. c). merancang strategi dan lingkungan pembelajaran dengan menyediakan berbagai pengalaman, belajar yang diperlukan mahasiswa dalam rangka mencapai kompetensi yang dibebankan pada mata yang diampu. d). membantu mahasiswa mengakses informasi, menata dan memprosesnya untuk dimanfaatkan dalam memecahkan permasalahan nyata. e). mengidentifikasi dan menentukan pola penilaian hasil belajar mahasiswa yang elemennya dengan kompetensi (Panduan Penyusunan Kurikulum SNPT, 2016: 46).

Hal ini juga selaras dengan apa yang disampaikan dalam wawancara dengan dosen AIK, yaitu (hasil wawancara pada tanggal 20 Mei 2019): "Kalau utuk metode pembelajaran itu pertama dilakukan SCL yaitu student center learning berpusat pada mahasiswa dosen hanya sebagai fasilitator dan motivator, kami selaku dosen merancang strategi saja bagaimana menyediakan lingkungan belajar, dan membantu mahasiswa dalam memecahkan masalah untuk mencari solusinya”. 


\section{Capaian Pembelajaran Mata Kuliah al-Islam Kemuhammadiyahan yang dibebankan pada Mahasiswa}

Pada dimensi ini mau melihat sejauh mana pemahaman mahasiswa setelah mengikuti perkuliahan al-Islam Kemuhammadiyahan sebagai kegiatan pembelajaran yang dilaksanakan secara nyata. Sehingga mahasiswa mendapatkan umpan balik yang memadai setelah mengikuti proses pembelajaran di dalam kelas. Dari hasil wawancara di atas menggambarkan bahwa mata kuliah al-Islam memang dapat dipahami mahasiswa dengan baik bagi mahasiswa yang berasal sekolahnya dari pesantren maupun madrasah, tetapi beban ujian akhir dari mata kuliah al-Islam Kemuhammadiayahan bagi mahasiswa yang berasal dari sekolah umum tentu menjadi kendala tersendiri dalam segi hafalan.

\section{Pembahasan}

Mata kuliah al-Islam Kemuhammadiyahan 1 biasa disebut dikalangan Pimpinan Universitas Muhammadiyah Palembang khususnya di Fakultas Ekonomi dan Bisnis, para ketua Program Studi Manajemen dan ketua Program Studi Akuntansi, para dosen di lingkungan Fakultas Ekonomi dan Bisnis, para staf dan karyawan Fakultas Ekonomi dan Bisnis serta mahasiswa-mahasiswi merupakan ciri khas mata kuliah wajib Universitas Muhammadiyah. Tetapi pada tahun 2016 ada himbauan dari Kementerian Riset, Teknologi dan Pendidikan Tinggi tentang Kerangka Kualifikasi Nasional Indonesia dan Standar Nasional Pendidikan Tinggi bahwa mata kuliah agama merupakan mata kuliah wajib nasional yang diberi nama pendidikan agama Islam.

Fakta teoritis inilah yang membuat mata kuliah al-Islam Kemuhammadiyahan 1 ini merupakan perwujudan dari mata kuliah wajib nasional yang menyesuaikan pada Standar Nasional Pendidikan Tinggi dengan nama mata kuliah Pendidikan Agama Islam dengan jumlah 2 sks. Tetapi penyebutan istilah dikalangan civitas Universitas Muhammadiyah Palembang pada saat ini tetap al-Islam Kemuhammadiyahan 1.

Mata kuliah al-Islam kemuhammadiyahan 1 adalah mata kuliah yang membahas mengenai dasar-dasar agama Islam, sumber-sumber hukum Islam, aqidah, ibadah, dasar-dasar akhlak dan muamalah. Yang bertujuan membentuk mahasiswa yang memiliki akhlak mulia dengan cara memahami ajaran-ajaran Islam dan aplikasinya dalam kehidupan sehari-hari dengan berpedoman pada Himpunan Putusan Tarjin Muhammadiyah.

Mata kuliah ini juga merupakan mata kuliah wajib Universitas Muhammadiyah Palembang dengan dikembangkan lagi menjadi al-Islam Kemuhammadiyahan 2 atau Fiqih Ibadah, al-Islam Kemuhammadiyahan 3 atau Gerakan Pembaharuan Islam, al-Islam Kemuhammadiyahan 4 atau Fiqih Islam, al-Islam Kemuhammadiyahan 5 atau Retorika, dan Pedoman Hidup Islami Warga Muhammadiyah, al-Islam Kemuhammadiyahan 6 atau Islam dan Ilmu Ekonomi. Untuk al-Islam Kemuhammadiyahan 6 ini menyeseuaikan dengan masing-masing Fakultas di Universitas Muhammadiyah misalnya dalam penelitian ini di Fakultas Ekonomi dan Bisnis yaitu Islam dan Ilmu Ekonomi.

Fakultas Ekonomi dan Bisnis Universitas Muhammadiyah Palembang merupakan Fakultas pilihan terfavorit di Universitas Muhammadiyah, bisa dilihat dengan data jumlah mahasiswanya yang terlampir. Memiliki dua Program Studi yaitu Program Studi Manajemen dan Program Studi Akuntansi. Dua Program Studi ini masing-masing memiliki konsentrasi, seperti di Program Studi Manajemen ada tiga konsentrasi yaitu manajemen keuangan, manajemen pemasaran dan manajemen sumber daya manusia. Sedangkan Program Studi Akuntansi ada konsentrasi Perpajakan, konsentrasi Auditing dan konsentrasi Akuntasi Sektor Publik. 
Maka sebagai lembaga pendidikan tinggi Fakultas Ekonomi dan Bisnis, sesuai dengan Standar Nasional Pendidikan Tinggi pasal 39 ayat (2) wajib: 1) melakukan penyusunan kurikulum dan rencana pembelajaran dalam setiap mata kuliah, 2) meyelenggarakan program pembelajaran sesuai dengan standar isi, standar proses dan standar penilaian yang telah ditetapkan dalam rangka mencapai capaian pembelajaran lulusan, 3) melakukan kegiatan sistematik yang menciptkan suasana akademik dan budaya mutu yang baik, 4) melakukan kegiatan pemantauan dan evaluasi secara periodik dalam rangka menjaga dan meningkatkan mutu proses pembelajaran dan, 5) melaporkan hasil program pembelajaran secara periodeik sebagai sumber data dan informasi dalam pengambilan keputusan perbaikan dan pengembangan mutu pembelajaran.

Universitas Muhammadiyah Palembang khususnya Fakultas Ekonomi dan Bisnis dalam mengelola pembelajaran salah satunya wajib melakukan pemantauan dan evaluasi terhadap kegiatan program studi dalam melaksanakan kegiatan pembelajaran. Oleh sebab itu, diperlukan kegiatan evaluasi program pembelajaran yang dapat digunakan sebagai tolak ukur keberhasilan dan perbaikan mutu pembelajaran atau pengembangan kurikulum.

Jadi Pembahasan dari hasil penelitian pertama, dokumen perencanaan pembelajaran semester mata kuliah al-Islam Kemuhammadiyahan 1 Fakultas Ekonomi dan Bisnis dengan panduan penyusunan rencana pembelajaran semester Standar Nasional Pendidikan Tinggi Berdasarkan hasil wawancara dengan Wakil Dekan I, Wakil Dekan IV, Ketua Program Studi Manajemen, Ketua Program Studi Manajemen dan dosen mata kuliah al-Islam Kemuhammadiyahan 1 (Pendidikan Agama Islam) menunjukkan bahwa proses penyusunan pembelajaran semester mata kuliah al-Islam Kemuhammadiyahan 1 (Pendidikan Agama Islam) disusun dengan beberapa kriteria Standar Nasional Pendidikan Tinggi: Nama Program Studi, nama dan kode, semester, sks mata kuliah, Nama dosen pengampu, Capaian pembelajaran lulusan yang dibebankan pada mata kuliah, kemampuan akhir yang direncanakan disetiap tahapan pembelajaran, materi pembelajaran, metode pembelajaran, waktu, pengalaman belajar mahasiswa, kriteria, indikator dan bobot penilaian, daftar referensi dan format rencana pembelajaran semester.

Dari hasil telaah dokumen mata kuliah al-Islam Kemuhammadiyahan 1 (Pendidikan Agama Islam), menunjukan penyusunan yang terdapat dalam dokumen rencana pembelajaran semester mata kuliah al-Islam Kemuhammadiyahan 1 (Pendidikan Agama Islam) sudah memenuhi kriteria dari Standar Nasional Pendidikan Tinggi akan tetapi pada bagian metode pembelajaran dan indikator penilaian tidak menunjukkan kesesuaian dengan standar. Sehingga menjadi pertimbangan adalah dalam metode pembelajaran harus memuat unsur berupa metode diskusi kelompok, simulasi, studi kasus, pembelajaran kolaboratif, pembelajaran kooperatif, pembelajaran berbasis proyek, dan pembelajaran yang berbasis masalah. Sedangkan untuk pertimbangan indikator penilaian itu menunjukkan kualitas kinerja mahasiswa.

Berikut tabel data penyusunan rencana pembelajaran mata kuliah al-Islam Kemuhammadiyahan 1 (Pendidikan Agama Islam) model Countenance Stake dengan menggunakan matriks deskripsi dan matriks pertimbangan: 
Tabel 3. Penyusunan rencana pembelajaran mata kuliah al-Islam Kemuhammadiyahan 1 (Pendidikan Agama Islam)

\begin{tabular}{|c|c|c|c|}
\hline Komponen & Kriteria & Deskripsi & Pertimbangan \\
\hline & Nama program studi & Nama program studi & \\
\hline & $\begin{array}{l}\text { Nama dan kode, semester, } \\
\text { sks mata kuliah }\end{array}$ & $\begin{array}{l}\text { Nama dan kode, } \\
\text { semester, sks mata } \\
\text { kuliah }\end{array}$ & - \\
\hline & Nama dosen pengampu & $\begin{array}{l}\text { Nama dosen } \\
\text { pengampu }\end{array}$ & - \\
\hline & $\begin{array}{l}\text { Capaian pembelajaran } \\
\text { lulusan yang dibebankan } \\
\text { pada mata kuliah }\end{array}$ & $\begin{array}{l}\text { Capaian pembelajaran } \\
\text { lulusan yang } \\
\text { dibebankan pada mata } \\
\text { kuliah }\end{array}$ & - \\
\hline \multirow[t]{8}{*}{$\begin{array}{c}\text { Rencana } \\
\text { pembelajaran } \\
\text { semester }\end{array}$} & $\begin{array}{l}\text { Kemampuan akhir yang } \\
\text { direncanakan di setiap } \\
\text { tahapan pembelajaran }\end{array}$ & $\begin{array}{l}\text { Kemampuan akhir } \\
\text { yang direncanakan di } \\
\text { setiap tahapan } \\
\text { pembelajaran }\end{array}$ & - \\
\hline & Materi pembelajaran & Materi pembelajaran & - \\
\hline & Metode pembelajaran & $\begin{array}{l}\text { Tidak menggunakan } \\
\text { kriteria unsur metode } \\
\text { pembelajaran SNPT }\end{array}$ & $\begin{array}{l}\text { Perbaikan dengan } \\
\text { menggunakan unsur } \\
\text { metode pembelajaran } \\
\text { SNPT }\end{array}$ \\
\hline & Waktu & Waktu & - \\
\hline & Pengalaman belajar & Pengalaman belajar & - \\
\hline & Kriteria, indikator penilaian & $\begin{array}{l}\text { Tidak menggunakan } \\
\text { indikator penilaian } \\
\text { SNPT }\end{array}$ & $\begin{array}{l}\text { Perbaikan dengan } \\
\text { menggunakan } \\
\text { indikator SNPT }\end{array}$ \\
\hline & Bobot penilaian & Bobot penilaian & - \\
\hline & Daftar referensi & Daftar referensi & - \\
\hline
\end{tabular}

Kedua, proses pembelajaran mata kuliah al-islam kemuhammadiyahan 1 fakultas ekonomi dan bisnis. Dari hasil wawancara dengan Wakil Dekan IV dan dosen mata kuliah alIslam Kemuhammadiyahan 1 (Pendidikan Agama Islam) serta mahasiswa Fakultas Ekonomi dan Bisnis, menunjukan proses pembelajaran yang dilaksanakan dalam mata kuliah al-Islam Kemuhammadiyahan 1 (Pendidikan Agama Islam) menunjukkan ketidaksesuaian dengan rencana pembelajaran semester mata kuliah al-Islam Kemuhammadiyahan, ketidakdisiplinan waktu dalam proses pembelajaran baik dari mahasiswa maupun dosen yang mengajar mata kuliah al-Islam Kemuhammadiyahan. Sehingga waktu yang direncanakan dalam dokumen rencana pembelajaran semester mata kuliah tidak berjalan dengan efektif sehingga dilakukan penambahan jam berikutnya. Untuk menjadi pertimbangan dosen perlu menkaji ulang mengenai ketepatan waktu yang telah ditentukan dalam perencanaan dengan apa yang dilaksanakan.

Selain itu juga antara dokumen rencana pembelajaran dengan proses pembelajaran yang dilaksanakan ada ketidaksesuaian dalam merumuskan rencana metode pembelajaran dengan apa yang dilaksanakan di dalam kelas. Seperti dalam dokumen dituliskan perkuliahan dilakukan dalam bentuk elaborasi, bukan metode pembelajaran seperti halnya diskusi, tanya jawab. Berikut tabel data proses pembelajaran mata kuliah al-Islam Kemuhammadiyahan 1 (Pendidikan Agama Islam) model Countenance Stake dengan menggunakan matriks deskripsi dan matriks pertimbangan: 
Tabel 4. proses pembelajaran mata kuliah al-Islam Kemuhammadiyahan 1 (Pendidikan Agama Islam)

\begin{tabular}{|c|c|c|c|}
\hline Komponen & Kriteria & Deskripsi & Pertimbangan \\
\hline \multirow{13}{*}{$\begin{array}{c}\text { Proses } \\
\text { Pembelajaran }\end{array}$} & $\begin{array}{l}\text { Prinsip pembelajaran: } \\
\text { Interaktif, }\end{array}$ & Interaktif & - \\
\hline & Holisitik, & Holistik & - \\
\hline & Integratif, & Integratif & - \\
\hline & Saintifik, & Saintifik & - \\
\hline & Kontekstual, & Kontekst & - \\
\hline & Tematik, & & - \\
\hline & Efektif, & Tidak efektif & $\begin{array}{c}\text { Perbaikan dalam } \\
\text { menyeseuaikan } \\
\text { keefektifan waktu } \\
\text { sesuai dengan rencana } \\
\text { pembelajaran } \\
\text { semester }\end{array}$ \\
\hline & $\begin{array}{c}\text { Berpusat pada } \\
\text { mahasiswa, }\end{array}$ & $\begin{array}{l}\text { Berpusat pada } \\
\text { mahasiswa, }\end{array}$ & - \\
\hline & $\begin{array}{l}\text { Prinsip penilaian: } \\
\text { Edukatif, }\end{array}$ & Edukatif & - \\
\hline & Otentik, & Otentik & - \\
\hline & Objektif, & Objektif & - \\
\hline & Akuntabel, & Akuntabel & - \\
\hline & Transparan. & Transparan & - \\
\hline
\end{tabular}

Dan ketiga, dari hasil wawancara dengan mahasiswa Fakultas Ekonomi dan Bisnis mengenai pemahaman mahasiswa dalam pembelajaran mata kuliah al-Islam Kemuhammadiyahan 1 menunjukkan bahwa mahasiswa bisa memahami dasar-dasar agama Islam sesuai dengan tuntunan yang benar yang dicontohkan oleh Rasulullah SAW dalam kehidupan sehari-hari seperti yang ada pada capaian pembelajaran mata kuliah al-Islam Kemuhammadiayahan. Dan mengamalkan kewajibannya sebagai seornag muslim mendirikan shalat, zakat, puasa, bersedekah, bersikap siddiq, tabligh, amanah, dan fatanah dalam kehidupan sehari-harinya baik untuk diri sendiri, lingkungan keluarga, dan lingkungan masyarakat. Berikut tabel data pemahaman mahasiswa dalam mengikuti mata kuliah al-Islam Kemuhammadiyahan 1 (Pendidikan Agama Islam) model Countenance Stake dengan menggunakan matriks deskripsi dan matriks pertimbangan:

Tabel 5. Capaian mata kuliah yang dibebankan pada mahasiswa

\begin{tabular}{|c|c|c|c|}
\hline Komponen & Kriteria & Deskripsi & Pertimbangan \\
\hline \multirow{3}{*}{$\begin{array}{l}\text { Capaian Mata Kuliah } \\
\text { al-Islam } \\
\text { Kemuhammadiyahan } \\
1\end{array}$} & $\begin{array}{l}\text { Mahasiswa mampu } \\
\text { memahami dasar-dasar agama } \\
\text { Islam dan sumber hukum } \\
\text { dalam Islam }\end{array}$ & $\begin{array}{l}\text { Mahasiswa memahami } \\
\text { dasar-dasar agama Islam } \\
\text { dan sumber hukum } \\
\text { dalam Islam yang sudah } \\
\text { dijelaskan dosen }\end{array}$ & - \\
\hline & $\begin{array}{l}\text { Mahasiswa mampu } \\
\text { memahami dan mengamalkan } \\
\text { dasar-dasar aqidah Islam dan } \\
\text { arkanul iman }\end{array}$ & $\begin{array}{l}\text { Mahasiswa memahami } \\
\text { dan berusaha } \\
\text { mengamalkan dasar- } \\
\text { dasar aqidah Islam dan } \\
\text { arkanul iman }\end{array}$ & - \\
\hline & $\begin{array}{l}\text { Mahasiswa mampu } \\
\text { memahami dan } \\
\text { menginternalisasikan tauhid } \\
\text { kepada Allah SWT dalam } \\
\text { kehidupan sehari-hari }\end{array}$ & $\begin{array}{l}\text { Mahasiswa memahami } \\
\text { dan berusaha } \\
\text { menginternalisasikan } \\
\text { tauhid kepada Allah } \\
\text { SWT dalam kehidupan } \\
\text { sehari-hari }\end{array}$ & - \\
\hline
\end{tabular}




Mahasiswa mampu
memahami dan mengamalkan
dasar-dasar ibadah, akhlak,
dan muamalah dalam Islam
serta klasifikasi dan prinsip-
prinsipnya.

\author{
Mahasiswa memahami \\ dan berusaha \\ mengamalkan dasar- \\ dasar ibadah, akhlak, \\ dan muamalah dalam \\ Islam serta klasifikasi \\ dan prinsip-prinsipnya.
}

\section{KESIMPULAN}

Pertama, dokumen yang terdapat pada rencana pembelajaran semester mata kuliah alIslam Kemuhammadiyahan 1 (Pendidikan Agama Islam) sudah memenuhi kriteria dari Standar Nasional Pendidikan Tinggi akan tetapi pada bagian metode pembelajaran dan indikator penilaian tidak memenuhi kriteria dari Standar Nasional Pendidikan Tinggi. Kedua, proses pembelajaran mata kuliah al-Islam kemuhammadiyahan 1 Fakultas Ekonomi dan Bisnis menunjukkan adanya ketidaksesuaian dengan dokumen rencana pembelajaran semester mata kuliah al-Islam Kemuhammadiyahan yaitu penggunaan waktu yang tidak efektif dalam proses pembelajaran di kelas baik dari mahasiswa maupun dosen yang mengajar mata kuliah al-Islam Kemuhammadiyahan. Selain itu, antara dokumen rencana pembelajaran dengan proses pembelajaran yang dilaksanakan ada ketidaksesuaian dalam merumuskan rencana metode pembelajaran dengan apa yang digunakan di dalam kelas. Dan ketiga, mahasiswa memahami mata kuliah al-Islam Kemuhammadiyahan 1 yang diajarkan oleh dosen sesuai dengan capaian pembelajaran mata kuliah al-Islam Kemuhammadiyah 1 tentang dasar-dasar agama Islam sesuai dengan tuntunan yang dicontohkan oleh Rasulullah SAW dalam kehidupan sehari-hari.

\section{DAFTAR PUSTAKA}

Dawam, A. (2004). Pendidikan Terpadu Sebagai Sebuah Sistem Pendidikan Nasional Alternatif Sebuah Pikiran Sederhana. Yogyakarta: Ar-Ruzz.

Hasan, S. H. (2012). Evaluasi Kurikulum. Bandung: Remaja Rosdakarya.

Nizam, M. (2006). Tantangan Pendidikan di Era Globalisasi. Bandung: Remaja Rodakarya.

Noer, D. (1999). Gerakan Modern Islam di Indonesia. Jakarta: LP3ES.

Muhammadiyah, P. P. (2005). Tanfidz Keputusan Muktamar Muhammadiyah 45. Malang: Pimpinan Pusat Muhammadiyah. 